\title{
Isoprenaline in complete heart block patients during ambulance transport
}

\author{
Taraknath Taraphdhar*, Sreekanth Reddy Basireddy \\ From EMCON 2014: International Conference on Emergency Medicine; 16th Annual Conference by the \\ Society for Emergency Medicine in India (SEMI) \\ Mumbai, India. 6-9 November 2014
}

\section{Objectives}

Isoprenaline has been recommended for short term treatment of heart block by the World Health Organization (2004), Australasian Resuscitation Council (2009), and UK Resuscitation Council (2010) guidelines. This study aims to ascertain the role of Isoprenaline in management of complete heart block during ambulance transport.

\section{Methods}

Retrospective study based on medical records of adult patients with documented history of Complete Heart Block and transported by ambulance of The Mission Hospital, Durgapur, from January 2011 to June 2014. Data was analyzed by simple statistical methods.

\section{Results}

98 (69 male and 29 female) such patients were transported, and 13 were on Temporary Pacemakers. 97 were inter-hospital transfers. 43 (44.3\%) patients were transported with Isoprenaline (average dose $2.7 \mathrm{mcg} / \mathrm{min}$, range 1 to $8.2 \mathrm{mcg} / \mathrm{min}$ ); 8 with Dopamine, and 7 on external cardiac pacing. 30 patients were on Isoprenaline and 8 on Dopamine in previous hospitals, and the same drug with similar dose was initially continued in the ambulance.

Out of the 84 patients transported without temporary pacemaker, 60 patients were transported within $20 \mathrm{~km}$ (travel time less than 30 minutes), 22 from distance between 50 to $100 \mathrm{~km}$ (average travel time 90 minutes) and 3 patients were transported beyond $100 \mathrm{kms}$. The longest distance patients travelled with Isoprenaline infusion was $525 \mathrm{~km}$ (travel time 26 hours). 6 (14\%) patients with Isoprenaline showed side effects and dose had to be reduced. Isoprenaline was replaced by Dopamine in one of

* Correspondence: tanatarafdar@yahoo.co.in

The Mission Hospital, Durgapur, West Bengal, India them. 4 of them travelled distance between 60 to $70 \mathrm{~km}$ and 2 beyond $100 \mathrm{~km} .34$ (79\%) patients with Isoprenaline achieved heart rates above $60 / \mathrm{min}$.

\section{Limitation}

This study is based on only one EMS operator and primarily on inter-hospital transfer.

\section{Conclusion}

Isoprenaline can be an effective and safe drug for transport of complete heart block patients over short distances. Further study is required for their safety in long distance travel.

Published: 22 April 2015

\section{doi:10.1186/1865-1380-8-S1-P3}

Cite this article as: Taraphdhar and Basireddy: Isoprenaline in complete heart block patients during ambulance transport. International Journal of Emergency Medicine 2015 8(Suppl 1):P3.

Submit your manuscript to a SpringerOpen ${ }^{\bullet}$ journal and benefit from:

- Convenient online submission

- Rigorous peer review

- Immediate publication on acceptance

- Open access: articles freely available online

- High visibility within the field

Retaining the copyright to your article

Submit your next manuscript at $>$ springeropen.com

\section{SpringerOpen ${ }^{\circ}$}

(c) 2015 Taraphdhar and Basireddy; licensee Springer. This is an Open Access article distributed under the terms of the Creative Commons Attribution License (http://creativecommons.org/licenses/by/4.0), which permits unrestricted use, distribution, and reproduction in any medium, provided the original work is properly cited. 